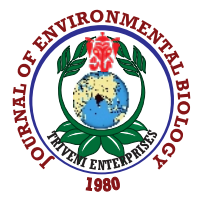

\title{
Soil fertility status of Ratte Khera farm of Punjab Agricultural University, Punjab, India
}

\section{R. Bhatt ${ }^{1 *}$ and Sanjay-Swami ${ }^{2}$}

${ }^{1}$ Regional Research Station, Kapurthala, Punjab Agricultural University, Ludhiana -141 004, India

${ }^{2}$ School of Natural Resource Management, College of Post Graduate Studies in Agricultural Sciences, (Central Agricultural University), Umiam (Barapani)-793 103, India

*Corresponding Author Email : rajansoils@pau.edu

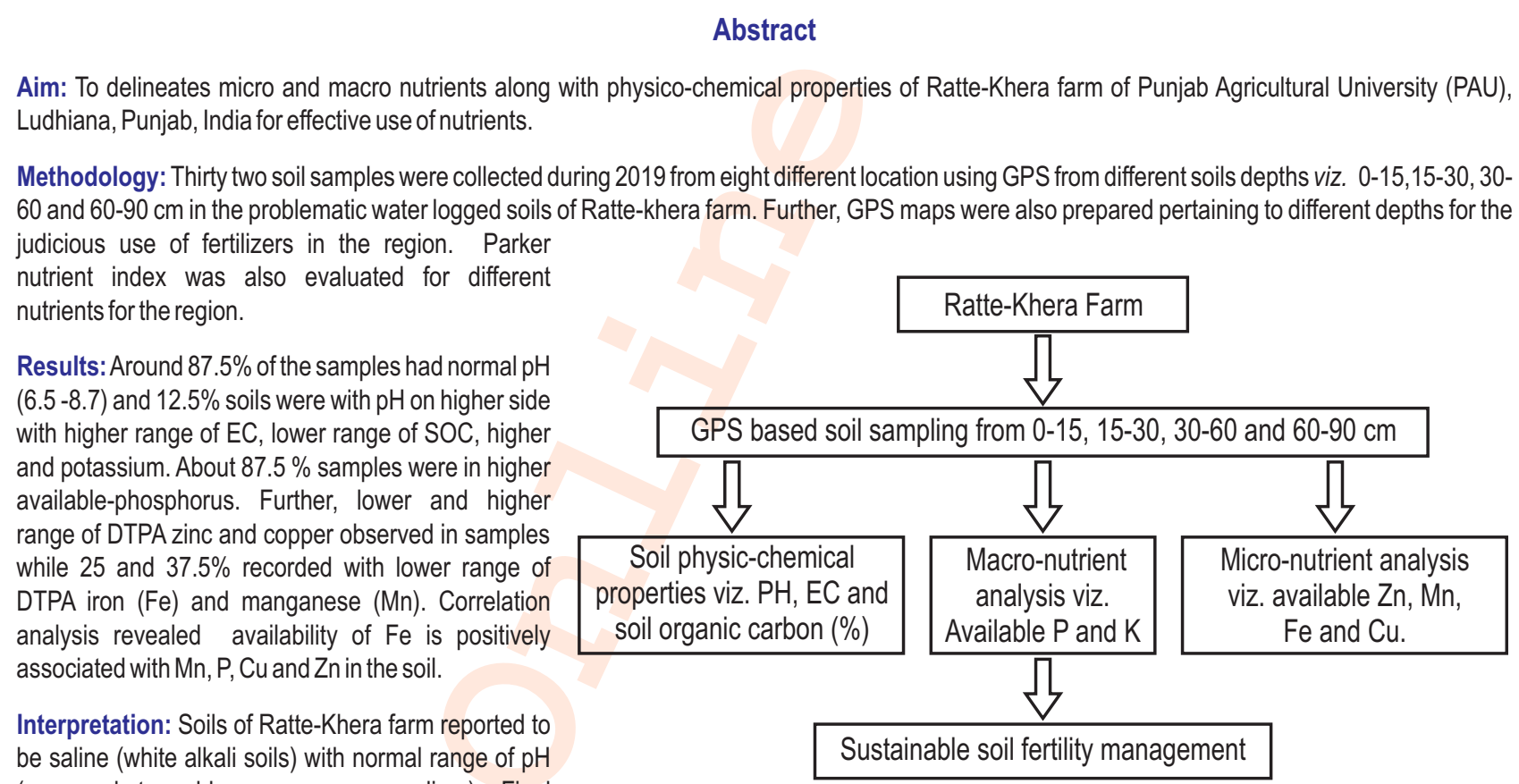
(no need to add any gypsum or lime). Final recommendation is to apply $25 \%$ higher dose of nitrogenous $(\mathrm{N})$ and phosphatic $(\mathrm{P})$ fertilizers with no need for potassic fertilizers. Further, micro-nutrients should be applied as and when symptoms observed on the field crops.

Key words: Nutrients, Parker Nutrient Index, Ratte-Khera, Soil fertility

How to cite : Bhatt, R. and Sanjay-Swami: Soil fertility status of Ratte Khera farm of Punjab Agricultural University, Punjab, India. J. Environ. Biol., 41, 1665-1675(2020). 


\section{Introduction}

Salt affected soils cover about seven million hectares in the Indo-Gangetic plains, of which 0.7 million hectares are in the state of Punjab alone (Abrol and Bhumbla, 1971) having illite, chlorite, smectite and kaolinite with occasionally fractions of vermiculite (Jassal et al., 2004). Crop yields are generally lower due to higher salt contents but now requires attention for feeding the ever increasing population (Lal, 2015; Wang et al., 2020). For which soil testing and scheduling fertilization thereof, is the only way towards judicious use of fertilizers, thereby increasing fertilizer use efficiency (Bhatt et al., 2020; Singh et al., 2019) and sustainable agriculture (Bhatt and Singh, 2020a,b). Degradation of soil health, lowering down of water table, diminishing soil organic matter status, increase in insect-pest and diseases attack and deficiency of micro- nutrients are some of the sustainability issues (Bhatt et al., 2016). Saline alkali soils can destroy the ecological main function areas through salinization and alkalinization of soils in arid or semi-arid areas (Lou et al., 2016, Sim et al., 2004). For enriching soil solution, chemical fertilizers must be broadcasted during critical periods of plant growth for meeting their nutrient requirements. Over or under fertilization is an important reason for lower yields than potential in the region due to difference between inherent fertility status of soil and nutrient requirement of crops (Ray et al., 2000). Micronutrients deficiencies have major constraint to agricultural productivity, stability and sustainability of soils (Bell and Dell, 2008), which is further affected by presence of macronutrients due to either negative or positive interactions (Fageria, 2001, Dadhich and Somani, 2007). Available Zn, Cu, Fe and Mn, already reported to be 36, 0.5, 4 and 5 percent are deficient in soil (Benbi et al., 2006), which further adversely affect the attainable yields. Soil fertilization only fill the gap between "How much nutrients is required for potential yields" and "How much nutrients is supplied by soils". Injudicious fertilizer use has resulted in higher number of leaf-chewing insects or mites attack due to enhanced leaf softness, underground water pollution, production of green house gases, higher cost of cultivation and finally to low yield and, hence, livelihoods (Bhatt, 2013; Bhatt and Singh, 2017). Further, nutrient dynamic in the soil system ensures the long-term sustainability. Keeping this in mind, contemporary research was conducted at Research Station of Ratte-Khera (representing South-Western Punjab, India) with an objective to delineate inherent fertility status of soils (pertaining to physico-chemical properties along with macro and micro nutrients) for practising sustainable agriculture in saline-alkali soils of the region.

\section{Materials and Methods}

Experimental site: Covering an area of 5 acres, Research Farm of Ratte-Khera (located at Muktsar district) of Punjab Agricultural University, Ludhiana, Punjab is an important research farm for waterlogged and salt affected agricultural research (Fig. 1). The Farm is located at $30^{\circ} 17.873^{\prime} \mathrm{N}$ longitude and $74^{\circ} 25.240^{\prime} \mathrm{E}$

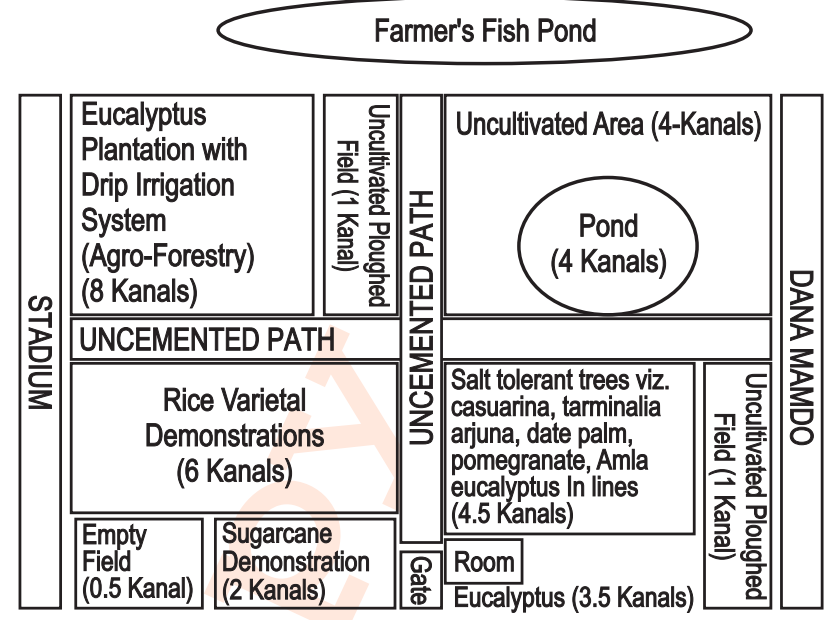

Fig. 1 : Map of Research Station of Ratte-Khera.

latitude with higher salt affected upper water table. During August 2019, 32 soil samples were collected from eight representative spots, while at that time, different crops viz. sugarcane $(0.25$ acre), rice (0.75 acre0), agro-forestry (1.5 acres) grown while around 0.5 acre area was between ponds while ponds pertains to an area of 0.5 acre. However, 0.44 acre area still remained uncultivated while rest of the area was under furrows and pathways. As far climate is concerned, the summers are hot, while winters are cold. The average minimum and maximum temperature varied from $0.8^{\circ}$ to $1.0^{\circ} \mathrm{C}$ and $41.8^{\circ}$ to $47.0^{\circ} \mathrm{C}$ in winters and summers, respectively. Rainfall from July to September with an average of $650 \mathrm{~mm}$. The soil texture of the area varied from sandy loam to loamy texture.

Collection and chemical analyses of soil samples: Using standard procedure (Andreas and Berndt, 2005), 32 soil samples were collected from all the farm at 0-15, 15-30, 30-60 and 60-90 cm depth with their GPS locations using GPS-60 (GARMIN) during August 2019. All the samples were air dried, crushed with pestle and mortar, and sieved through $2.0 \mathrm{~mm}$ stainless steel sieve to obtain a uniform sample and stored in cloth bags. Soil texture was estimated by feel method. The soil pH and EC in 1:2 soil: water solution were estimated by the method of Jackson (1967). Soil organic carbon was estimated by Walkley and Black's wet digestion and rapid titration method (Walkley and Black, 1934). Available phosphorus and potassium contents were determined using $0.5 \mathrm{M} \mathrm{NaHCO}_{3}$ extract (Olsen et al., 1954) and 1 $\mathrm{N}$ ammonium acetate $(\mathrm{pH} 7)$ extract, respectively (Jackson 1967). Available zinc, iron, manganese and copper contents in the soil were estimated by diethylen-triamine-penta acetic acid (DTPA) method (Lindsay and Norvell, 1978) on atomic absorption spectrophotometer.

Parker's Nutrient Index: Single value of each nutrient is required for making comparison of fertility of one area with that of another for which Parker's Nutrient Index (Parker et al., 1995) was 
calculated.

$$
\text { PNI }=\frac{\left(X 1 \times 1+X_{2} \times 2+X_{3} \times 3\right)}{\text { Total number of samples }}
$$

$X_{1}=$ Number of samples which are low; $X_{2}=$ Number of samples which are medium; $X_{3}=$ Number of samples which are high; PNI below $1.67,1.67$ to 2.33 and higher than 2.33 reported to be in the lower, medium and higher ranges, respectively.

\section{Results and Discussion}

\section{Physico-chemical soil properties}

Soil pH : The pH of soil at Research Farm, Ratte-Khera at 0-15 cm (Fig. 5), $15-30 \mathrm{~cm}, 30-60 \mathrm{~cm}$ and $60-90 \mathrm{~cm}$ ranged from 8.10 to 9.10 with mean values of $8.62,8.46,8.56$ and 8.63 from spots $A$ to $\mathrm{H}$, respectively, with overall mean of 8.57 (Table 1 and 2). Upto $0-15 \mathrm{~cm}, 30-60 \mathrm{~cm}$ and $60-90 \mathrm{~cm}, 12.5 \%, 37.5 \%$ and $50 \%$ samples were observed to be in higher range $(>8.7)$, while from $15-30 \mathrm{~cm}$ all the samples fell within the normal range (Fig. 2). Higher soil pH in some of the fields may be due to soluble and exchangeable sodium ions along with bicarbonate ions, which precipitate as calcium and magnesium carbonate during evaporation (Deshmukh, 2012; More et al., 1988). Correlation analysis revealed that $\mathrm{pH}$ was negatively and significantly related with available $\mathrm{P}, \mathrm{Fe}$ and $\mathrm{Cu}$, while negatively and non-significantly with $\mathrm{EC}, \mathrm{OC}, \mathrm{K}$ and $\mathrm{Mn}$ and acidic condition increase the availability of $\mathrm{P}, \mathrm{Fe}$ and $\mathrm{Cu}$ (Fig. 4). Similar results of negative correlation between $\mathrm{pH}$ and available $\mathrm{P}$ has been reported by Bhatt and Singh (2017; 2020) (pH range 6.7 to 8.27); Kumar et al., 2017 (8.01 to 10.63).

Soil EC: EC of the soils at Research Farm, Ratte-Khera at 0-15 $\mathrm{cm}, 15-30 \mathrm{~cm}, 30-60 \mathrm{~cm}$ and $60-90 \mathrm{~cm}$ ranged from 0.35 to 1.58 with mean values of $0.93,0.88,0.76$ and 0.66 from spots $A$ to $H$, respectively, with overall mean of 0.81 (Table 1 and 2). Upto 0-15 cm (Fig. 5), $15-30 \mathrm{~cm}$ and $30-60 \mathrm{~cm} \mathrm{100 \% ,25 \%} \mathrm{and} 25 \%$

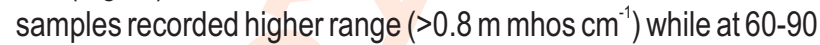
$\mathrm{cm}$ all samples recorded to be in the normal range (Table 1 and 2 ). Correlation analysis revealed that EC was positively and significantly related to available $\mathrm{Zn}$ and Fe (Fig. 4) but nonsignificantly with other analyzed parameters. Therefore, lesser EC will decrease the availability of Fe and $\mathrm{Zn}$. Similar results were also reported by Bhatt and Singh $(2017 ; 2020)$ in Tarn Taran and Kapurthala districts, but in non-significant manner.

Soil texture: The texture of soil at Research Farm, Ratte-Khera varied from sandy loam to loamy (Table 1). Analysis revealed that surface soils of spots $A, B, C, D$ and $H$ were sandy-loam, while spots $E, F$ and $G$ had loamy textured with deeper depths being sandy-loam soils.

Soil organic carbon: Soil organic carbon expresses the soil

Table 1 : Delineation of special variation physico-chemical properties, macro and micronutrients ( $\left.\mathrm{mg} \mathrm{kg}^{-1}\right)$ at Research Farm, Ratte-Khera from 0-15 and $15-30 \mathrm{~cm}$ soil depth

\begin{tabular}{|c|c|c|c|c|c|c|c|c|c|c|c|c|}
\hline Spots & Longitude & Latitude & Texture & $\mathrm{pH}_{\text {(n }}$ & $\begin{array}{c}\text { EC } \\
\text { mhos c }\end{array}$ & $\mathrm{OC}(\%)$ & $\begin{array}{l}\text { Avail. } \\
\text { P }\end{array}$ & $\begin{array}{l}\text { Avail. } \\
\mathrm{K}\end{array}$ & $\begin{array}{l}\text { Avail. } \\
\text { Zn }\end{array}$ & $\begin{array}{l}\text { Avail. } \\
\text { Fe }\end{array}$ & $\begin{array}{l}\text { Avail. } \\
\text { Mn }\end{array}$ & $\begin{array}{l}\text { Avail. } \\
\mathrm{Cu}\end{array}$ \\
\hline \multicolumn{13}{|c|}{$0-15 \mathrm{~cm}$} \\
\hline A & $\mathrm{N} 30^{\circ} 17.873^{\prime}$ & $\mathrm{E} 74^{\circ} 25.255^{\prime}$ & $S L$ & 8.50 & 1.01 & 0.36 & 13.40 & 153.00 & 0.46 & 20.48 & 3.96 & 0.96 \\
\hline B & N30⒘871' & $\mathrm{E} 74^{\circ} 25.268^{\prime}$ & $S L$ & 8.70 & 0.92 & 0.21 & 0.40 & 84.00 & 0.12 & 8.90 & 2.18 & 0.64 \\
\hline C & N30 $17.854^{\prime}$ & $\mathrm{E} 74^{\circ} 25.290^{\prime}$ & $S L$ & 8.80 & 0.96 & 0.36 & 4.30 & 90.00 & 0.28 & 27.26 & 9.34 & 1.36 \\
\hline D & N30⒘830' & $\mathrm{E} 74^{\circ} 25.289^{\prime}$ & $S L$ & 8.50 & 0.89 & 0.30 & 2.60 & 150.00 & 0.20 & 20.34 & 7.06 & 0.98 \\
\hline$E$ & $\mathrm{~N} 30^{\circ} 17.819^{\prime}$ & $\mathrm{E} 74^{\circ} 25.258^{\prime}$ & $\mathrm{L}$ & 8.75 & 0.92 & 0.09 & 0.90 & 165.00 & 0.16 & 2.06 & 2.14 & 1.20 \\
\hline $\mathrm{F}$ & N30⒘817' & $\mathrm{E} 74^{\circ} 25.233^{\prime}$ & $\mathrm{L}$ & 8.60 & 0.94 & 0.09 & 0.40 & 120.00 & 0.26 & 2.72 & 3.10 & 1.28 \\
\hline G & N30⒘862' & $\mathrm{E} 74^{\circ} 25.238^{\prime}$ & $\mathrm{L}$ & 8.60 & 0.87 & 0.12 & 0.90 & 150.00 & 0.08 & 5.64 & 7.76 & 1.48 \\
\hline \multirow[t]{3}{*}{$\mathrm{H}$} & N30⒘861' & $\mathrm{E} 74^{\circ} 25.226^{\prime}$ & SL & 8.52 & 0.94 & 0.15 & 2.60 & 105.00 & 0.18 & 12.70 & 8.28 & 1.70 \\
\hline & & & Mean & 8.62 & 0.93 & 0.21 & 3.19 & 127.13 & 0.22 & 12.51 & 5.48 & 1.20 \\
\hline & \multicolumn{12}{|c|}{$15-30 \mathrm{~cm}$} \\
\hline A & N30 $17.873^{\prime}$ & $\mathrm{E} 74^{\circ} 25.255^{\prime}$ & SL & 8.50 & 1.54 & 0.24 & 8.70 & 111.00 & 0.44 & 21.72 & 4.84 & 1.12 \\
\hline B & N30 $17.871^{\prime}$ & $\mathrm{E} 74^{\circ} 25.268^{\prime}$ & $S L$ & 8.60 & 0.74 & 0.18 & 1.80 & 111.00 & 0.08 & 3.12 & 2.04 & 0.62 \\
\hline C & N30⒘854' & $\mathrm{E} 74^{\circ} 25.290^{\prime}$ & $\mathrm{L}$ & 8.80 & 0.83 & 0.18 & 0.40 & 90.00 & 0.18 & 3.20 & 5.26 & 1.00 \\
\hline D & $\mathrm{N} 30^{\circ} 17.830^{\prime}$ & $\mathrm{E} 74^{\circ} 25.289^{\prime}$ & $S L$ & 8.20 & 1.12 & 0.48 & 12.50 & 159.00 & 0.32 & 23.30 & 4.74 & 1.42 \\
\hline$E$ & $\mathrm{~N} 30^{\circ} 17.819^{\prime}$ & $\mathrm{E} 74^{\circ} 25.258^{\prime}$ & $\mathrm{L}$ & 8.70 & 0.68 & 0.15 & 18.40 & 189.00 & 0.12 & 2.52 & 2.52 & 0.84 \\
\hline $\mathrm{F}$ & N $30^{\circ} 17.817^{\prime}$ & $\mathrm{E} 74^{\circ} 25.233^{\prime}$ & L & 8.40 & 0.74 & 0.12 & 3.40 & 96.00 & 0.12 & 2.86 & 1.88 & 0.90 \\
\hline G & N $30^{\circ} 17.862^{\prime}$ & $\mathrm{E} 74^{\circ} 25.238^{\prime}$ & $\mathrm{L}$ & 8.40 & 0.71 & 0.12 & 2.60 & 141.00 & 0.10 & 5.32 & 6.16 & 1.70 \\
\hline \multirow[t]{2}{*}{$\mathrm{H}$} & N $30^{\circ} 17.861^{\prime}$ & $\mathrm{E} 74^{\circ} 25.226^{\prime}$ & $\mathrm{SL}$ & 8.10 & 0.68 & 0.33 & 11.50 & 102.00 & 0.28 & 32.30 & 10.94 & 1.56 \\
\hline & & & Mean & 8.46 & 0.88 & 0.23 & 7.41 & 124.88 & 0.21 & 11.79 & 4.80 & 1.15 \\
\hline
\end{tabular}


Table 2 : Delineation of special variation physico-chemical, macro and micronutrients $\left(\mathrm{mg} \mathrm{kg}^{-1}\right)$ at Research Farm, Ratte-Khera from 30-60 and 60-90 $\mathrm{cm}^{-1}$ soil depths

\begin{tabular}{|c|c|c|c|c|c|c|c|c|c|c|c|c|}
\hline Spots & Longitude & Latitude & Texture & $\mathrm{pH}$ & $\begin{array}{l}\mathrm{EC}(\mathrm{m} \\
\left.\mathrm{mhos} \mathrm{cm}^{-1}\right)\end{array}$ & $\mathrm{OC}(\%)$ & $\begin{array}{l}\text { Avail. } \\
\text { P }\end{array}$ & $\begin{array}{l}\text { Avail. } \\
\mathrm{K}\end{array}$ & $\begin{array}{l}\text { Avail. } \\
\mathrm{Zn}\end{array}$ & $\begin{array}{l}\text { Avail. } \\
\text { Fe }\end{array}$ & $\begin{array}{l}\text { Avail. } \\
\mathrm{Mn}\end{array}$ & $\begin{array}{l}\text { Avail. } \\
\mathrm{Cu}\end{array}$ \\
\hline \multicolumn{13}{|c|}{$30-60 \mathrm{~cm}$} \\
\hline A & N30o 17.873' & $E 74^{\circ} 25.255^{\circ}$ & SL & 9.10 & 1.04 & 0.12 & 0.90 & 189.00 & 0.16 & 2.56 & 2.34 & 0.90 \\
\hline B & $\mathrm{N} 30^{\circ} 17.871^{\prime}$ & $\mathrm{E} 74^{\circ} 25.268^{\prime}$ & SL & 8.80 & 0.35 & 0.15 & 0.40 & 111.00 & 0.10 & 3.64 & 1.88 & 0.62 \\
\hline C & $\mathrm{N} 30^{\circ} 17.854^{\prime}$ & $\mathrm{E} 74^{\circ} 25.290^{\prime}$ & SL & 9.10 & 0.35 & 0.15 & 0.40 & 99.00 & 0.16 & 12.00 & 6.34 & 0.98 \\
\hline D & $\mathrm{N} 30^{\circ} 17.830^{\prime}$ & $\mathrm{E} 74^{\circ} 25.289^{\prime}$ & SL & 8.20 & 1.58 & 0.15 & 2.60 & 99.00 & 0.18 & 10.80 & 5.38 & 1.06 \\
\hline$E$ & $\mathrm{~N} 30^{\circ} 17.819^{\prime}$ & $\mathrm{E} 74^{\circ} 25.258^{\prime}$ & SL & 8.40 & 0.69 & 0.06 & 2.60 & 144.00 & 0.10 & 3.04 & 1.96 & 0.94 \\
\hline $\mathrm{F}$ & $\mathrm{N} 30^{\circ} 17.817^{\prime}$ & $\mathrm{E} 74^{\circ} 25.233^{\prime}$ & SL & 8.30 & 0.67 & 0.09 & 1.80 & 129.00 & 0.14 & 12.08 & 8.46 & 1.26 \\
\hline G & N $30^{\circ} 17.862^{\prime}$ & $\mathrm{E} 74^{\circ} 25.238^{\prime}$ & $\mathrm{L}$ & 8.40 & 0.70 & 0.15 & 1.80 & 192.00 & 0.14 & 7.46 & 4.90 & 1.42 \\
\hline \multirow[t]{3}{*}{$\mathrm{H}$} & $\mathrm{N} 30^{\circ} 17.861^{\prime}$ & $\mathrm{E} 74^{\circ} 25.226^{\prime}$ & SL & 8.20 & 0.70 & 0.15 & 2.60 & 111.00 & 0.10 & 9.26 & 6.34 & 1.14 \\
\hline & & & Mean & 8.56 & 0.76 & 0.13 & 1.64 & 134.25 & 0.14 & 7.61 & 4.70 & 1.04 \\
\hline & \multicolumn{12}{|c|}{$60-90 \mathrm{~cm}$} \\
\hline$A$ & $\mathrm{~N} 30^{\circ} 17.873^{\prime}$ & $\mathrm{E} 74^{\circ} 25.255^{\prime}$ & SL & 8.70 & 0.68 & 0.12 & 0.40 & 90.00 & 0.12 & 1.64 & 1.28 & 0.56 \\
\hline B & $\mathrm{N} 30^{\circ} 17.871^{\prime}$ & $\mathrm{E} 74^{\circ} 25.268^{\prime}$ & SL & 8.80 & 0.31 & 0.12 & 0.40 & 81.00 & 0.08 & 2.00 & 1.28 & 0.50 \\
\hline C & $\mathrm{N} 30^{\circ} 17.854^{\prime}$ & $\mathrm{E} 74^{\circ} 25.290^{\prime}$ & SL & 9.00 & 0.65 & 0.18 & 0.40 & 99.00 & 0.10 & 3.48 & 5.52 & 0.82 \\
\hline D & $\mathrm{N} 30^{\circ} 17.830^{\prime}$ & $\mathrm{E} 74^{\circ} 25.289^{\prime}$ & SL & 9.10 & 0.85 & 0.15 & 0.40 & 108.00 & 0.10 & 3.78 & 5.26 & 1.06 \\
\hline $\mathrm{E}$ & N $30^{\circ} 17.819^{\prime}$ & $\mathrm{E} 74^{\circ} 25.258^{\prime}$ & SL & 8.40 & 0.74 & 0.12 & 1.80 & 132.00 & 0.10 & 4.82 & 2.46 & 0.84 \\
\hline $\mathrm{F}$ & $\mathrm{N} 30^{\circ} 17.817^{\prime}$ & $\mathrm{E} 74^{\circ} 25.233^{\prime}$ & SL & 8.30 & 0.69 & 0.12 & 0.90 & 156.00 & 0.12 & 6.64 & 5.50 & 1.26 \\
\hline G & N30⒘862' & $E 74^{\circ} 25.238^{\prime}$ & $\mathrm{L}$ & 8.40 & 0.68 & 0.24 & 2.60 & 183.00 & 0.16 & 7.76 & 2.54 & 1.00 \\
\hline \multirow[t]{2}{*}{$\mathrm{H}$} & N30⒘861' & $\mathrm{E} 74^{\circ} 25.226^{\prime}$ & SL & 8.30 & 0.70 & 0.21 & 4.30 & 150.00 & 0.18 & 1.88 & 1.10 & 0.64 \\
\hline & & & Mean & 8.63 & 0.66 & 0.16 & 1.40 & 124.88 & 0.12 & 4.00 & 3.12 & 0.84 \\
\hline
\end{tabular}
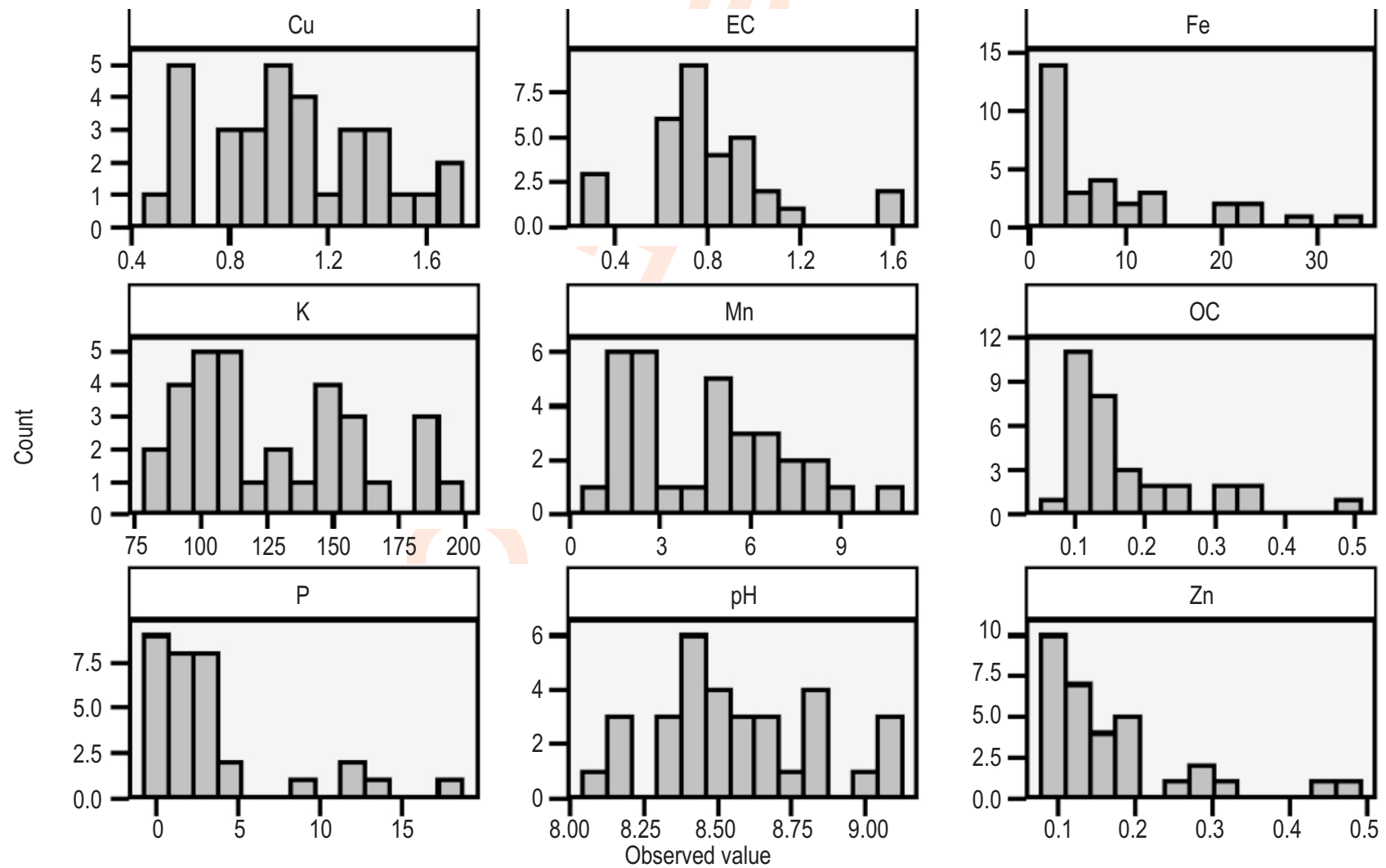

Fig. 2 : Sample count falling in different categories under different physico-chemical properties and macro and micro nutrients at Research Farm, RatteKhera. 

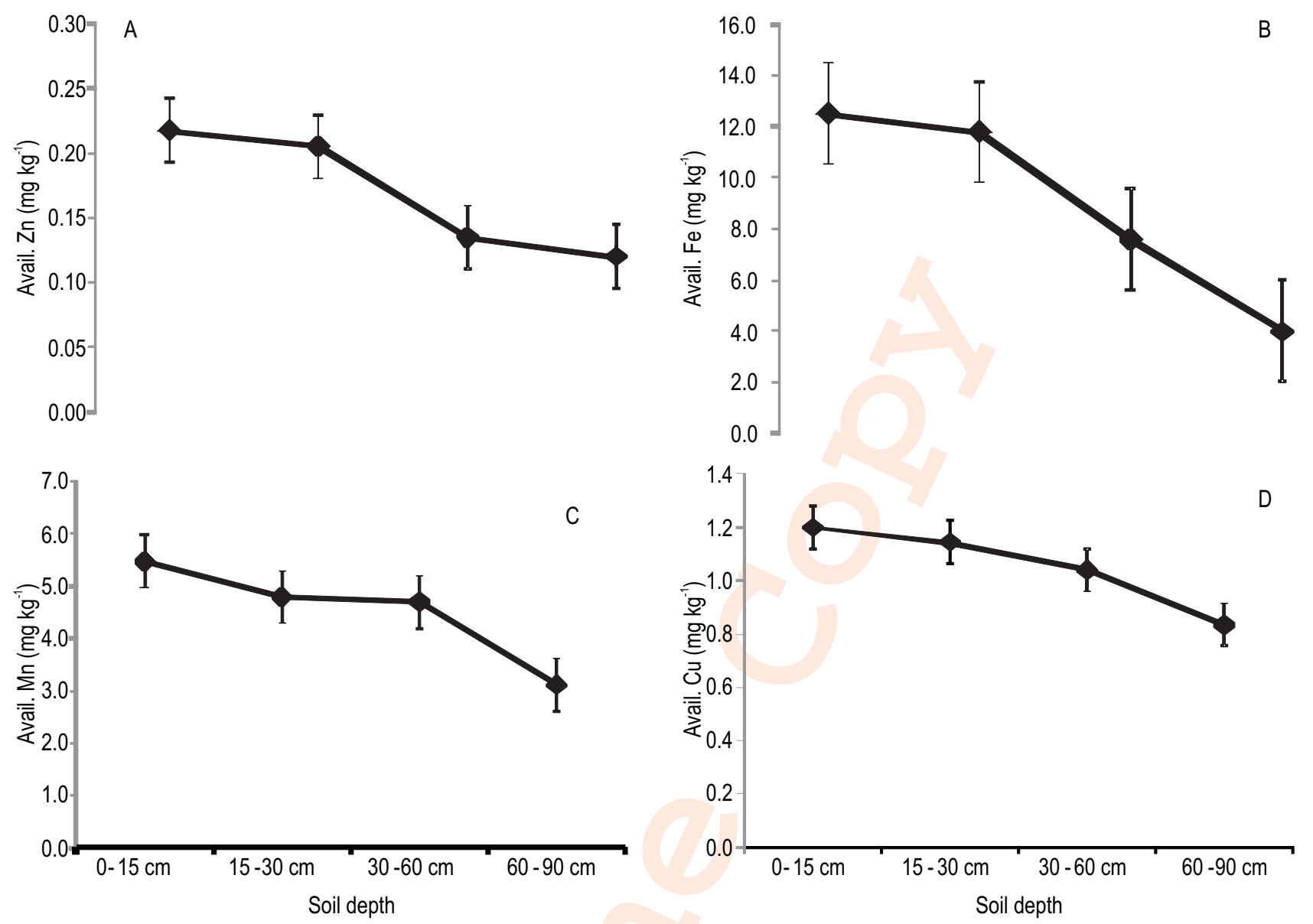

Fig. 3 : Depth-wise variation of micronutrient content $\left(\mathrm{mg} \mathrm{kg}^{-1}\right)$, zinc (A), iron (B), manganese (C) and copper D) at Research station, Ratte-Khera, Punjab (Bars show standard errors).

Table 3 : Parker's Nutrient Index of soil organic carbon, available P and available K in soils upto $90 \mathrm{~cm}$ depth of study sites

\begin{tabular}{llll}
\hline Spots & SOC & Available P & Available K \\
\hline A & 1.0 & 1.75 & 3.00 \\
B & 1.0 & 1.00 & 3.00 \\
C & 1.0 & 1.00 & 3.00 \\
D & 1.25 & 1.00 & 3.00 \\
E & 1.0 & 1.00 & 3.00 \\
F & 1.0 & 1.00 & 3.00 \\
G & 1.0 & 1.00 & 3.00 \\
H & 1.0 & 1.00 & 3.00 \\
Mean & 1.13 & 1.375 & 3.00 \\
\hline
\end{tabular}

organic matter content which further influences soil physicochemical properties and better response to applied N-fertilizers (Johnston, 1986). SOC status of the Research Farm, RatteKhera from surface to $90 \mathrm{~cm}$ deep soil varied from $0.06 \%$ to $0.48 \%$ with mean values of $0.21,0.23,0.13$ and $0.16 \%$ from $0-15$ (Fig. 5), 15-30, 30-60 and 60-90 cm soil depths, respectively. Further, all the analyzed spots at $0-15,30-60$ and $60-90 \mathrm{~cm}$ of soil depth had lower range of $S O C(<0.4 \%)$. At $15-30 \mathrm{~cm}$ depth, spot D had medium range of SOC ( 0.4 to $0.75 \%$ ), majority soil samples were in low SOC category except D spots at $15-130 \mathrm{~cm}$ (Table 1 and 2). Lower range of SOC throughout the spots and all depths might be due to poor vegetation cover because of higher salt

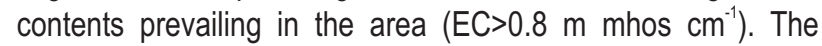
nutrient index of SOC, across all the spots was in the low range (1.00) (Table 3). Correlation analysis revealed that SOC was positively and significantly related with available Fe, Zn, P and Mn 
Table 4 : Percentage of soil samples falling in different ranges of pH, EC, OC (\%), available P, K, Zn, Fe, Cu and Mn at $0-15 \mathrm{~cm}$ soil depth at study area

\begin{tabular}{llll}
\hline Parameter & Value & Rating & \% age of samples falling \\
\hline $\mathrm{pH}(1: 2)$ & $6.5-8.7$ & Normal & 12.5 \\
& $8.7-9.3$ & Alkaline & 87.5 \\
$\mathrm{EC}(1: 2)$ & $>9.3$ & Sodic & - \\
& $<0.8$ & Normal & - \\
$\mathrm{OC}(\%)$ & $>0.8$ & Saline & 100 \\
& $<0.4$ & Low & - \\
& $0.4-0.75$ & Medium & - \\
Available $\mathrm{P}\left(\mathrm{mg} \mathrm{kg}^{-1}\right)$ & $>0.75$ & High & 12.5 \\
& $<5$ & & 87.5 \\
& $5-9$ & Low & - \\
Available $\mathrm{K}_{2} \mathrm{O}\left(\mathrm{mg} \mathrm{kg}^{-1}\right)$ & $>20$ & Medium & - \\
& $<55$ & High & 100 \\
Available $\mathrm{Zn}\left(\mathrm{mg} \mathrm{kg}^{-1}\right)$ & $>55$ & Low & 100 \\
& $<0.6$ & High & - \\
Available Fe $\left(\mathrm{mg} \mathrm{kg}^{-1}\right)$ & $>0.6$ & Low & 25.0 \\
& $<4.5$ & High & 75.0 \\
Available Cu $\left(\mathrm{mg} \mathrm{kg}^{-1}\right)$ & $>4.5$ & Low & - \\
Available $\mathrm{Mn}\left(\mathrm{mg} \mathrm{kg}^{-1}\right)$ & $>0.2$ & High & 100 \\
& $>0.2$ & Low & 37.5 \\
& $>3.5$ & High & 62.5 \\
\hline
\end{tabular}

while non-significantly related with $\mathrm{K}, \mathrm{Mn}$ and $\mathrm{Cu}$ (Fig. 4). Therefore, lower the OC $(\%)$, lesser the availability of available $\mathrm{Fe}, \mathrm{Zn}, \mathrm{P}$ and $\mathrm{Mn}$. Hence, application of different organic manures i.e., farm yard manure is recommended.

\section{Macro-nutrients status of soil}

Available phosphorus: Available phosphorus content (mean value all spots from $A$ to $H$ ) in the soils of area were $3.19,7.41,1.64$ and $1.40 \mathrm{mg} \mathrm{kg}^{-1}$ in 0-15, 15-30, 30-60 and 60-90 cm, respectively, with overall mean of $3.41 \mathrm{mg} \mathrm{kg}^{-1}$ (Table 1) which is in lower range (Fig. 5). At $0-15 \mathrm{~cm}$ soil depth, P status was found to be higher only atAspot (12.5\%), while at 15-30 cm soil depth, spotA had lower, D, $\mathrm{E}$ and $\mathrm{H}$ spot had medium while other with lower range of available P. Further, at 30-60 and 60-90 cm soil depth, all the spots were with lower range $\left(<5 \mathrm{mg} \mathrm{kg}^{-1}\right)$. Across the analyzed depths, average range of available $P$ was noted to be 0.4 to $18.40 \mathrm{mg} \mathrm{kg}^{-1}$. Nutrient index were observed to be in lower range at all the sampled spots from $\mathrm{A}$ to $\mathrm{H}$ (Table 2) and their ranges are delineated in Table 4. On an average, available-P was less than $5 \mathrm{mg} \mathrm{kg}^{-1}$ (low) at $0-15,30$ 60 and $60-90 \mathrm{~cm}$, while found to be in the middle range at $15-30 \mathrm{~cm}$ soil depth at Ratte-Khera (Table 1, 2). Therefore, present study stress on soil test based $P$ application. Correlation analysis revealed that available $\mathrm{P}$ was positively and significantly related to $\mathrm{OC}$, available $\mathrm{Zn}$ and $\mathrm{Fe}$, while positively and non-significantly with others, except $\mathrm{pH}$, indicating higher $\mathrm{pH}$ decreases the availability of $P$ (Fig. 4). Hence, mostly $P$ status particularly in upper surface soils reported to be in lower range (Fig. 5).
Available potassium: On an average, the mean available potash level at Research Farm, Ratte-Khera from $\mathrm{A}$ to $\mathrm{H}$ spots was $127.13,124.88,134.25$ and $124.88 \mathrm{mg} \mathrm{kg}^{-1}$ at $0-15,15-30$, $30-60$ and $60-90 \mathrm{~cm}$, respectively, with an overall mean value of $127.8 \mathrm{mg} \mathrm{kg}^{-1}$ (Table 1, 2). Further, all the spots at all depths were in the higher range $\left(>55 \mathrm{mg} \mathrm{kg}^{-1}\right)$. On an average, $\mathrm{K}$ status varied from 81 to $192 \mathrm{mg} \mathrm{kg}^{-1}$. Present investigation revealed that all the spots from $\mathrm{A}$ to $\mathrm{H}$ throughout the soil depths from 0 to $90 \mathrm{~cm}$ had higher range of $\mathrm{PNI}$ (Table 2). Further, almost all the samples had more than $55 \mathrm{mg} \mathrm{kg}^{-1}$ (high) (Fig. 2). Correlation analysis revealed that available $\mathrm{K}$ was non-significantly and positively related to EC, OC (\%), available $\mathrm{Zn}$ and $\mathrm{Cu}$, while non-significantly and negatively related to $\mathrm{pH}$, available Fe and $\mathrm{Mn}$, respectively (Fig. 4) indicating that available $\mathrm{K}$ is not affected by variability of other nutrients. Further their ranges are delineated in Table 4. Available, K status particularly on upper surface is reported to be in higher range (Fig. 5).

Micronutrient status of soils : Micronutrient deficiencies have become one of the major constraints in sustaining crop production in the present exploitive agriculture. These deficiencies appeared much faster in the northern states as compared to other parts of the country, which may be attributed primarily to the fast adoption of new agricultural technology, including: cultivation of high yielding crop varieties, increase in cropping intensity, expansion of irrigation facilities, increased use of high analysis fertilisers, and poor quality irrigation water (Nayyar, 1999). 


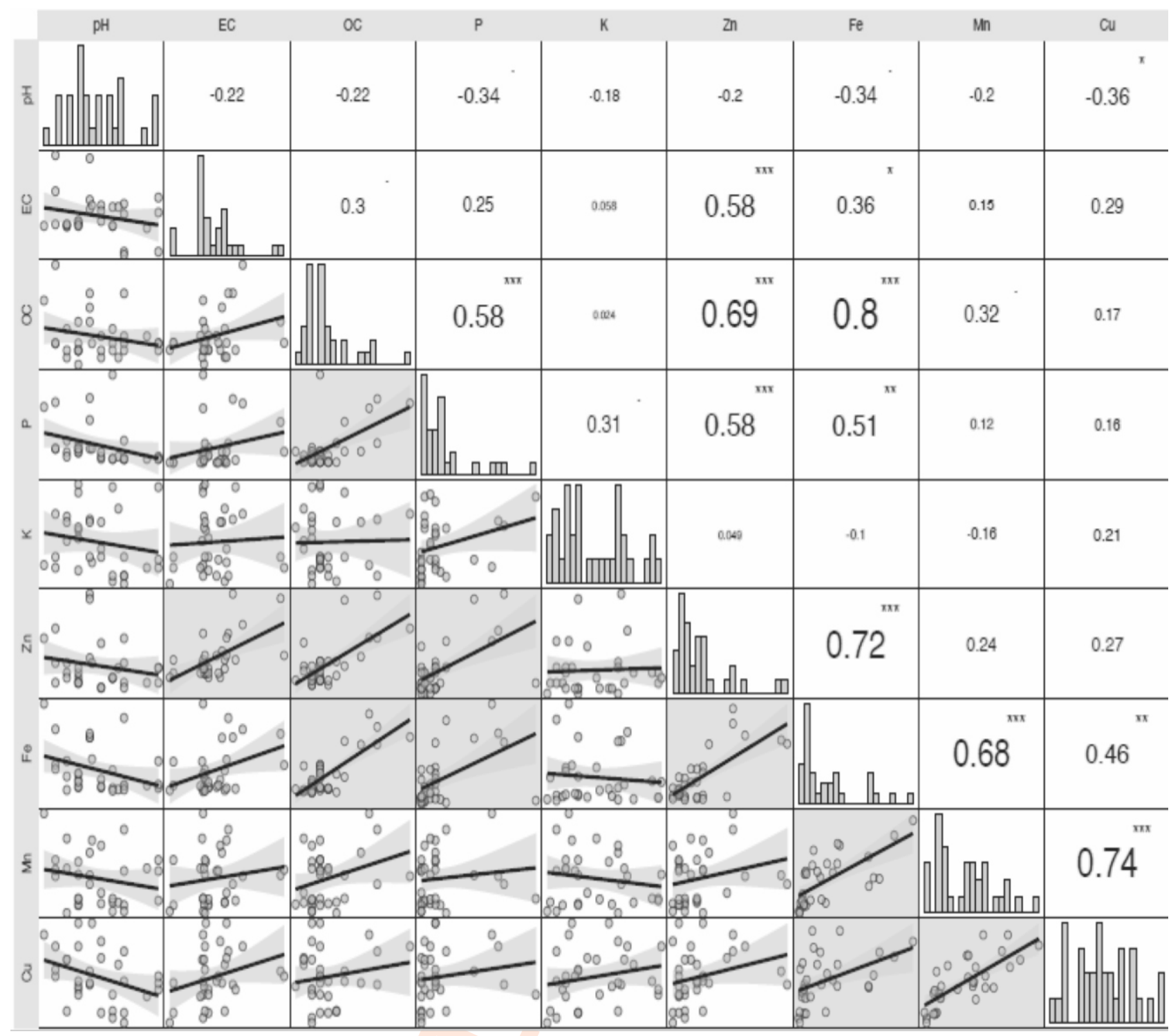

Fig. 4 : Correlation matrix between soil physic-chemical properties, available micro and macro nutrients at Research Farm, Ratte-Khera.

Available zinc: Considering $0.60 \mathrm{mg} \mathrm{kg}^{-1}$, of available zinc as threshold limit, Zn status was found to be in lower range $(<0.6 \mathrm{mg}$ $\mathrm{kg}^{-1}$ ) across all the spots (from $A$ to $\mathrm{H}$ ) and soil depths (from 0-15, 15-30, 30-60 and 60-90 cm), emphasizing need for Zn application (Table 1 and 2). Further their ranges are delineated in Table 4. The mean values across the soil depth was $0.22,0.21,0.14$ and 0.12 $\mathrm{mg} \mathrm{kg}^{-1}$ across all the analyzed spots, with an overall mean of 0.17 $\mathrm{mg} \mathrm{kg}^{-1}$ (Fig. 3). Available Zn status range varied from 0.08-0.46, $0.10-0.44,0.10-0.18$ and $0.08-0.18 \mathrm{mg} \mathrm{kg}^{-1}$ from all the analyzed soil depths, respectively (Fig. 2). Further, available Zn range was found to be in lower side, particularly in the above surface soils (Fig. 6). Correlation analysis revealed that available Zn was significantly and positively related to available Fe, indicating that higher availability of Fe favours $\mathrm{Zn}$ supply, while it was non- significantly and negatively cor-related to soil pH, EC, OC (\%), available $P$ and $K$. Further, available $\mathrm{Zn}$ was reported with available $\mathrm{Mn}$ and $\mathrm{Cu}$ in a positive but in a non-significant manner (Fig 4). Similar trends reported by Bhatt and Singh, 2020.

Available iron: Considering $4.50 \mathrm{mg} \mathrm{kg}^{-1}$ of available iron as the threshold limit, Fe status was found to vary as per different samples at $0-15 \mathrm{~cm}$ depth, samples pertaining to $E$ and $F$ spots while at $15-30 \mathrm{~cm}$ depth, samples pertaining to $B, C, E$ and $F$ falls in the lower range (Table 1). However, at $30-60 \mathrm{~cm}$, samples of $A, B$ and $E$ spots were in lower range $\left(<4.5 \mathrm{mg} \mathrm{kg}^{-1}\right)$ while at $60-90 \mathrm{~cm}$, spots $A, B, C, D$ and $H$ had lower range values (Table 2). The mean values across the soil depth was 12.51,11.79, 7.61 and 4.0 $\mathrm{mg} \mathrm{kg}^{-1}$, with an overall mean of $8.98 \mathrm{mg} \mathrm{kg}^{-1}$ (Fig. 3). Further, 

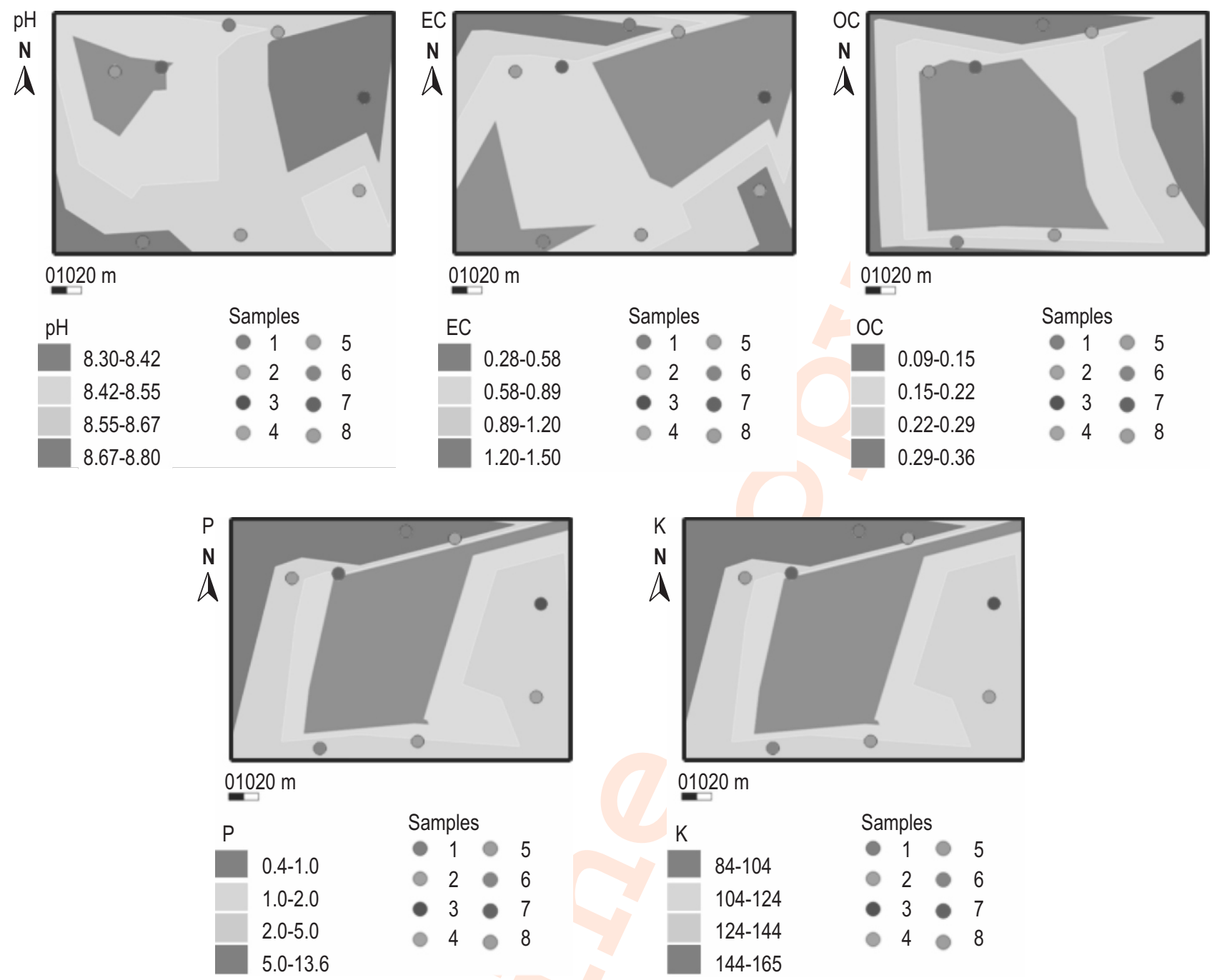

Fig. 5 : Digital soil maps of Ratte-Khera farm pertaining to different physico-chemical properties and macronutrients showing their distribution at top 15 cm soil depth.

available Fe range was reported to be in higher side particularly on the above surface soil (Fig. 6). Available Fe status range varied from 2.06-20.48, 2.52-32.30, 2.56-12.08 and 1.64-7.76 mg kg-1 from all the analyzed soil depths viz. 0-15, 15-30, 30-60 and 60$90 \mathrm{~cm}$, respectively (Fig. 2). Considering $4.50 \mathrm{mg} \mathrm{kg}^{-1}$ as critical limit for available Fe content, soil analysis showed that $75 \%$ of samples were in high category, while $25 \%$ samples fells in the low range (Fig. 2). Correlation analysis revealed that available Fe was significantly and positively related with $\mathrm{OC}(\%)$, available $\mathrm{P}, \mathrm{Zn}$, $\mathrm{Mn}$ and $\mathrm{Cu}$, while negatively and non-significantly with $\mathrm{pH}$, available K, respectively (Fig. 4). Crops like sugarcane and maize may require $\mathrm{FeSO}_{4}$ spray to overcome Fe deficiency. Further, their ranges are delineated in Table 4.

Available manganese: Considering $3.5 \mathrm{mg} \mathrm{kg}^{-1}$, of available manganese as threshold limit, Mn status varied in different samples at $0-15 \mathrm{~cm}$ depth, samples pertaining to $A, E$ and $F$ spots, while at $15-30 \mathrm{~cm}$ depth, samples pertaining to $B, E$ and $F$ fell in the lower range (Table 1). However, at $30-60 \mathrm{~cm}$, samples of $A, B$ and $E$ spots were in lower range $\left(<3.5 \mathrm{mg} \mathrm{kg}^{-1}\right)$ while at $60-90 \mathrm{~cm}$, spots $A, B, E, G$ and $H$ lower range values (Table 2). The mean values across the soil depths were $5.48,4.80,4.70$ and $3.12 \mathrm{mg}$ $\mathrm{kg}^{-1}$, with an overall mean of $4.52 \mathrm{mg} \mathrm{kg}^{-1}$ (Fig. 3). Further, available $\mathrm{Mn}$ range reported to be in higher side particularly in the above surface soils (Fig. 6) while some spatial deficiencies were reported across the way. Available $\mathrm{Mn}$ status range varied from 2.14-8.28, 2.04-10.94, 1.88-8.46 and 1.10-5.52 $\mathrm{mg} \mathrm{kg}^{-1}$ from all the analyzed soil depths viz. 0-15, 15-30, 30-60 and 60-90 cm, respectively (Fig. 2). Considering $3.50 \mathrm{mg} \mathrm{kg}^{-1}$ as critical limit of Mn deficiency, $62.5 \%$ of soil samples were in sufficient range, while $37.5 \%$ samples were low in available Mn. (Table 3), thereby soil test based application may be required to control $\mathrm{Mn}$ deficiency in crops. Correlation analysis revealed that available 
$\mathrm{Zn}$

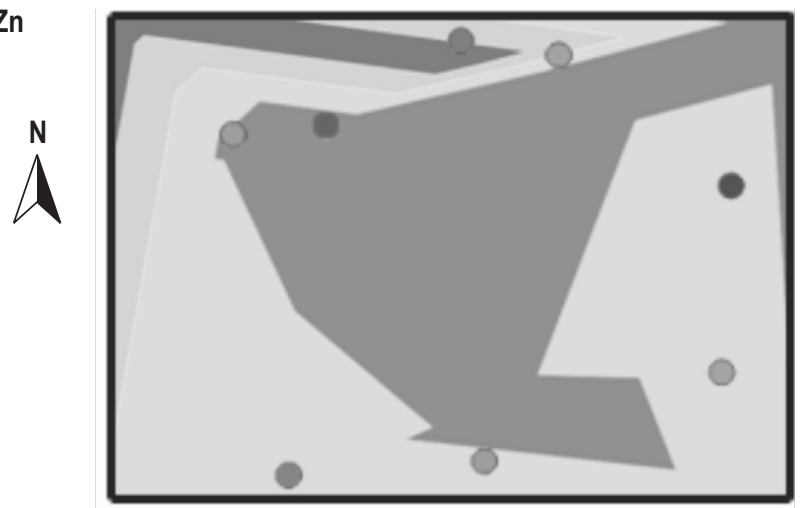

$01020 \mathrm{~m}$

$\mathrm{Zn}$

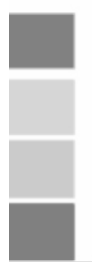

$0.08-0.18$

$0.18-0.29$

$0.29-0.39$

$0.39-0.50$

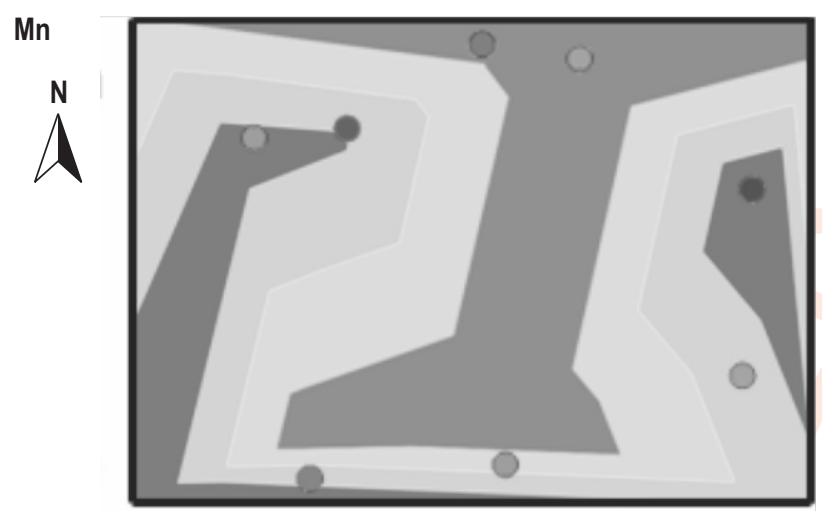

$01020 \mathrm{~m}$

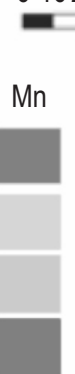

Samples

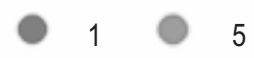

$2 \bigcirc 6$

$3 \bigcirc 7$

$4 \bigcirc 8$
$\mathrm{Fe}$

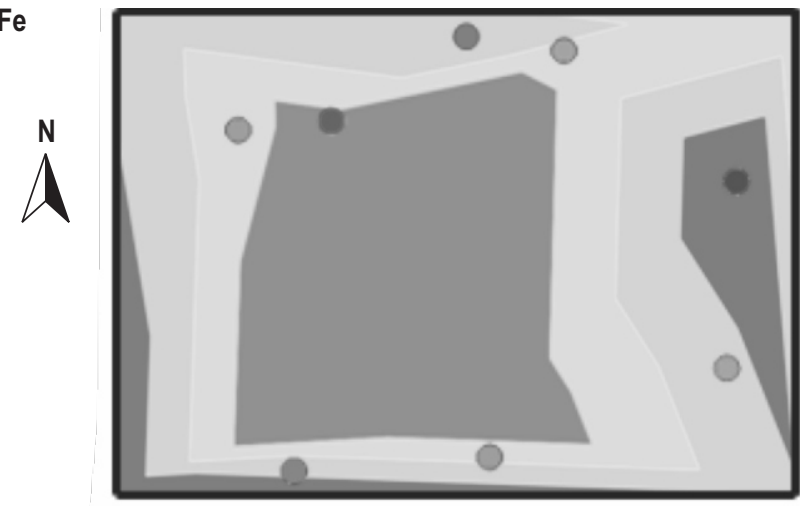

$01020 \mathrm{~m}$

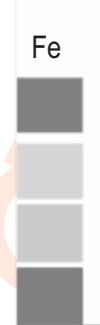

Samples

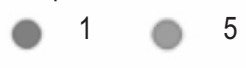

$2.06-8.36$

$8.36-14.66$

$14.66-20.96$

$20.96-27.26$
- $2 \bigcirc 6$

- $3 \bigcirc 7$

8
5

6

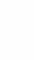

8

$\mathrm{Cu}$

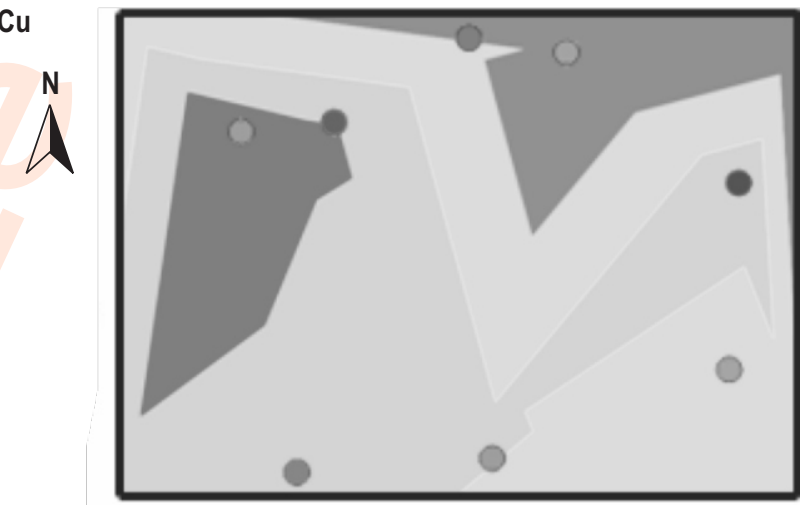

$01020 \mathrm{~m}$

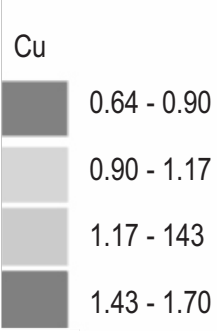


was reported to be in higher side, particularly in the above surface soils (Fig. 6). All soil samples either depth wise or spot wise from A to $\mathrm{H}$ contained $>0.20 \mathrm{mg} \mathrm{kg}^{-1}$ (above the critical limit) and, thus, no soil sample was deficient in available $\mathrm{Cu}$ (Table 3). Available $\mathrm{Cu}$ status range varied from 0.64-1.70, 0.62-1.70, 0.62-1.42 and $0.50-1.26 \mathrm{mg} \mathrm{kg}^{-1}$ from all the analyzed soil depths viz. 0-15, $15-$ $30,30-60$ and $60-90 \mathrm{~cm}$, respectively (Fig. 3). Further their ranges are delineated in Table 4. Available $\mathrm{Cu}$ was significantly and positively co-related to available $\mathrm{Fe}$ and available $\mathrm{Mn}$, respectively, while non-significantly with $\mathrm{pH}$ in a negative manure while positively with EC, OC, available $\mathrm{P}$, available $\mathrm{K}$ and $\mathrm{Zn}$ (Fig 4), as also earlier observed by Bhatt and Singh (2017; 2020); Bhatt, (2020).

As far as interactions among different physic-chemical properties and nutrients at Ratte-Khera are concerned, it was observed that interaction of $\mathrm{pH}$ with available $\mathrm{Cu}$, available $\mathrm{Fe}$ and available $P$ was negatively and strongly correlated than other negative correlations. Coming on the positive side, it revealed that $\mathrm{OC} \times$ available $\mathrm{Fe}$, available $\mathrm{Mn} \times$ available $\mathrm{Cu}$, available $\mathrm{Zn \times}$ available Fe, OCx available $Z n$ and available Fex Mn interactions are comparatively stronger and positively correlated (Fig. 4). Further, OC (\%) content increase the availability of Fe, Zn, P and $\mathrm{Mn}$ while high EC range increases the availability of Fe and $\mathrm{Zn}$. Acidic condition or lower $\mathrm{pH}$ value increase the availability of $\mathrm{P}, \mathrm{Fe}$ and $\mathrm{Cu}$. Availability of $\mathrm{Fe}$ is positively associated with $\mathrm{Mn}, \mathrm{P}, \mathrm{Cu}$ and $\mathrm{Zn}$ in the soil. Further, positive association between $\mathrm{Mn}$ with $\mathrm{Cu}$ and $\mathrm{P}$ with $\mathrm{Zn}$ were also reported (Fig. 4). Soil digital maps pertaining to different micronutrients viz. available Zn, Fe, CU and $\mathrm{Mn}$ (ppm) based on the GPS readings and soil analysis presented in the Fig. 6 showing their distribution in the top $15 \mathrm{~cm}$ soil depth.

The soils of Research Farm, Ratte-Khera are neutral in $\mathrm{pH}$ at $0-15,15-30 \mathrm{~cm}$ while slightly alkaline from $30-60$ and $60-90$ $\mathrm{cm}$, higher in the EC in upper 15 to $30 \mathrm{~cm}$, lower in $0 . \mathrm{C}(\%)$, higher to low, medium to lower, lower in the $0-15,15-30$ and $30-60$ and $60-90 \mathrm{~cm}$ in available $\mathrm{P}$, respectively and higher in available $\mathrm{K}$. Under micronutrients, available zinc and copper status was observed throughout in lower and higher range while available Fe and Mn had with spatial deficiencies, need to be addressed. Overall soils reported to be saline-alkali (white alkali soils) with normal range of $\mathrm{pH}$ (no need to add any gypsum or lime). Final recommendation is to apply $25 \%$ higher dose of $\mathrm{N}$ and $\mathrm{P}$ fertilizers with no need for potassic fertilizers. Further, spatial deficiencies reported for Fe (spots E, F), Mn (spots A, E and F) indicating their recommended sprays along with $\mathrm{Zn}$ spray. These recommendations also prove to be useful for farmers of the region, in improving their land productivity and ultimately livelihoods.

\section{References}

Abrol, I.P. and D.R. Bhumbla: World Soil Resources Report, No. 41, Food and Agriculture Organization, Rome (1971).

Andreas, P. and M.W. Berndt: Soil sampling and storage. In: Manual for soil analysis monitoring and assessing soil bioremediation (Eds.: R. Margesin and F. Schinner). Springer-Verlag: Berlin Heidelberg, pp. 3-13 (2005).

Bell, R.W. and B. Dell: Micronutrients for Sustainable Food, Feed, Fiber and Bio energy Production. IFA, Paris, France (2008).

Benbi, D.K., V.K. Nayyar and J.S. Brar: Green revolution in Punjab: The impact on soil health. Ind. J. Fertil., 2, 57-66 (2006).

Bhatt, R. and M. Sharma: Potassium Scenario- A case study in the Kapurthala district of Punjab, India. J. Res PAU., 48, 24-27 (2011).

Bhatt, R. and P. Singh: Delineating soil macro and micro nutrients in Tarn Taran district of Indian Punjab. J. Environ. Agri. Sci., 12, 25-34 (2017).

Bhatt, R. and P. Singh: Soil fertility status of Regional Research Station of Punjab Agricultural University, Kapurthala. J. Res. PAU., Accepted (2020a).

Bhatt, R. and P. Singh: Soil fertility status of University Seed Farm, Usman, Tarn Taran. J. Res. PAU., Accepted (2020b).

Bhatt, R., A. Hossain and P. Singh: Scientific interventions to improve land and water productivity for climate smart agriculture in SouthAsia (Ed.: M. Hasanuzzaman). Management Practices, Agronomic Crops, 2, pp. 499-558 (2020).

Bhatt, R.: Soil test based fertilization to improve production of oil seed crops in Kapurthala district of Punjab. Int. J. Sci. Environ. Technol., 2, 521-526 (2013).

Bhatt, R., S.S. Kukal., M.A. Busari, S. Arora and M. Yadav: Sustainability issues on rice-wheat cropping system. Int. Soil Water Conser. Res., 4, 64-74 (2016).

Bhatt, R.: Resources management for sustainable sugarcane production. In: Resources Use Efficiency in Agriculture (Eds.: S. Kumar, R.S. Meena and M.K. Jariya). Springer, pp. $650-685(2020)$

Chawla, V.K.: Available nitrogen and phosphorus status of saline-sodic soils of Punjab (India). Agron. J., 61, 361-362 (1969).

Dadhich, S.K. and L.L. Somani: Effect of integrated nutrient management in soybean-wheat crop sequence on the yield, micronutrient uptake and postharvest availability of micronutrients on typicustochrepts soil. ActaAgron., 55, 205-216 (2007).

Deshmukh, K.K.: Studies on chemical characteristics and classification of soils from Sangamner area, Ahmednagar district, Maharashtra, India. Rasayan. J. Chem., 5, 74-85 (2012).

Fageria, V.D.: Nutrient interactions in crop plants. J. Plant Nutr., 24, 12691290 (2001).

Jackson, M.L.: Soil Chemical Analysis. Prentice Hall of India Private Limited. New Delhi, pp. 234-246 (1967).

Jassal, H.S., J. Singh, J.S. Sawhney and B.D. Sharma: Geochemical environment and clay mineral formation of some salt affected soils of Punjab. International Conference on Sustainable Management of Sodic Lands held at Lucknow, pp. 156-158 (2004).

Johnston, A.E.: Soil organic matter, effects on soil and crop. Soil Use Manage., 2, 97-105(1986).

Kumar, D., S.R. Yadav., R. Kaur, A. Choudhary and B.S. Meena: Soil fertility status and nutrient recommendations based on soil analysis of Jaisalmer district of western Rajasthan. Asian J. Soil Sci., 12, 103-107 (2017).

Lal, R.: Restoring soil quality to mitigate soil degradation. Sustainability, 7,5875-5895 (2015)

Lindsay, W.L. and W.A. Norvell: Development of a DTPA soil test for zinc, iron, manganese, and copper. Soil Sci. Soc. Am. J., 42, 421-428 (1978).

More, S.D., J.S. Shinde and G.V. Malewar: Characterization of some salt 
affected soils of Puma command area of Maharashtra. J. Ind. Soc. Soil Sci., 36, 146-150 (1988).

Nayyar, V.K.: Micronutrient management for sustainable intensive agriculture. J. Ind. Soc. Soil Sci., 47, 666-680 (1999).

Olsen, S.R., C.V. Cole., F.S. Watanabe and L.A. Dean: Estimation of available phosphorus by extraction with sodium bicarbonate. USDACirc. 939, pp. 1-19(1954).

Parker, F.W., W.L. Nelson, E. Winters and J.E. Miles: The broad interpretation and application of soil test summaries. Agron. J., 43, 103-112 (1951).

Ray, P.K., A.K. Jana, D.N. Maitra, M.N. Saha, J. Chaudhury and S. Saha: Fertilizer prescriptions on soil test basis for jute, rice and wheat in a typic ustochrept. J. Ind. Soc. Soil Sci., 48, 79-84 (2000).

Rehman, O., B. Ahmad and S. Afzal: Soil fertility and salinity status of Attock district. J. Agric. Res., 48, 505-516 (2010).

Shukla, S.K.: Annual Report of All India coordinated research project on sugarcane. ICAR-Indian Institute of Sugarcane Research, Lucknow (2018)

Singh, Y.V., P. Dey, R.N. Meena, S.K. Verma and P.K. Bharteey: Soil test based fertilizer prescription model under integrated plant nutrient management system for pea on alluvial soil. J. Pharma. Phytochem., 8, 177-180 (2019).

Walkley, A. and I.A. Black: An examination of digestion method for determining soil organic matter and the proposed modification of the chromic acid titration method. Soil Sci., 37, 29-38 (1934).

Wang, S., T. Jie, L. Zhaoyang, L. Yuqing, Z. Zihao, J. Wang, Y. Qu and Z. Dai: Carbon mineralization under different saline-alkali stress conditions in paddy fields of North East China. Sustainability, 12, 2921 (2020).

Weil, R.R. and N.C. Brady: The nature and properties of soils. $15^{\text {th }}$ Edn., Publisher: Pearson Education, ISBN: 978-0133254488 (2016). 